\title{
CORPORATIONS: GOOD FAITH DEFENSE OF CORPORATE POLICY HELD SUFFICIENT TO JUSTIFY REPURCHASE OF STOCK WITH CORPORATE FUNDS
}

$\mathrm{C}$ stock, ${ }^{1}$ although the power is circumscribed by statutory and equitable limitations. Faced with broad enabling legislation, ${ }^{2}$ the Delaware Supreme Court in Cheff v. Mathes has sanctioned repurchases of stock when authorized by a board of directors to eliminate a "corporate raider." The court also indicated that a "good faith belief" in the preservation of "vital" management policies would be sufficient justification to permit the use of corporate funds and credit in enabling existing management to perpetuate its control.4

In Cheff, minority stockholders of Holland Furnace Company instituted a derivative action against the directors to recover corporate funds appropriated for the repurchase of Holland stock. Prior to the challenged stock purchase, the directors discovered that a Mr. Maremont and his controlled corporations had purchased a sizeable block of Holland stock. Investigation revealed Maremont's poor business reputation and his practice of realizing quick profits by the sale or liquidation of acquired companies. ${ }^{5}$ When Maremont made a buy-sell offer to the board of directors, they authorized the repurchase with corporate funds. ${ }^{\circ}$ Although the directors argued

1 ABA-ALI Model Bus. Corp. Act ANn. § 5, If 2.02 (1960, Supp. 1964); see Andersen v. Albert \& J. M. Anderson Mfg. Co., 325 Mass. 343, 90 N.E.2d 541 (1950); 6A Fletcher, Cyclopedia Corporations $\S 2854$ (perm. ed. rev. repl. 1950) [hereinafter cited as FLETCHER].

${ }^{2}$ DEL. CODE ANN. tit. 8, $\$ 160$ (1953), granting a corporation the power to purchase and sell shares of its own stock so long as the purchase does not result in the impairment of capital.

${ }^{8} 199$ A.2d 548 (Del. Sup. Ct. 1964).

See note 25 infra.

-An investigation of the financial and business history of Maremont and corporations controlled by him, information from "leading bank officials," and a Dunn \& Bradstreet report all indicated Maremont's active participation as a stockholder in past liquidation activities. 199 A.2d at 551, 556.

- Holland Furnace Company purchased 155,000 shares of its stock from a corporation controlled by Maremont. Id. at 552-53. At that time Holland had 883,585 shares outstanding, and the board of directors either owned or controlled approximately: 200,000 shares. Id. at 550 . The purchase price was $\$ 14.40$ per share, while the stock

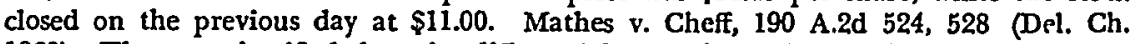
1963). The court justified the price differential as attributable to a "control premium." 199 A.2d at 555 . 
that the purchase was necessary to eliminate the threat to Holland's corporate existence and essential business policies, the vice-chancellor found that their primary motive was retention of control. ${ }^{7}$ The supreme court reversed, finding that the evidence established conclusively that the directors were motivated by a bona fide belief that they were protecting vital corporate policies. ${ }^{8}$

During the early years of the twentieth century, the minority American rule prohibited corporations from purchasing their own stock ${ }^{9}$ under the ultra vires analysis of English courts. ${ }^{10}$ Most jurisdictions followed the Massachusetts rule permitting solvent corporations to purchase their own shares if they acted according to the vaguely defined standards of good faith and without prejudice to the rights of creditors or other stockholders. ${ }^{11}$ A movement to modernize the statutory law of corporations led to the enactment of provisions restricting the majority common law rule. ${ }^{12}$ The great majority of states now provide that the purchase may be made only from surplus of one kind or another. ${ }^{13}$ Some also prohibit repurchase in all cases where the corporation is or would be thereby rendered insolvent. ${ }^{14}$

These arbitrary standards, or a requirement of stockholder approval, ${ }^{15}$ may preclude the use of repurchase as an efficient procedure

7 Mathes v. Cheff, supra note 6, at 529-30.

- 199 A.2d at 556. It was necessary for the corporation to borrow substantial sums of money from commercial lending institutions to finance the purchase. Id. at 552 . The court did not indicate, however, whether the statutory requirement of nonimpairment of capital was contravened. See DEL. Code ANN. tit. 8, § 160 (1953).

Ballantine, Corporations $\$ 256 a$ (rev. ed. 1946) [hereinafter cited as Baliantine]; 6A Fletcher § 2847. See, e.g., Maryland Trust Co. v. National Mechanics Bank, 102 Md. 608, 620-21, 63 Atl. 70, 77-79 (1906); Darnell-Love Lumber Co. v. Woggs, I44 Tenn. 113, 118-25, 230 S.W. 391, 392-94 (1921).

${ }^{10}$ Trevor v. Whitworth, 12 App. Cas. 409 (1887). The English rule is based on the theory that to allow repurchases would condone "an indirect method of reducing the capital stock, injuring creditors and other shareholders and allowing a corporation to traffic in its own shares, which is ultra vires." Nemmers, The Power of a Corporation to Purchase Its Own Stock, 1942 WIs. L. REv. 161. See authorities cited note 9 supra.

12 6A Fletcher \$ 2848; Wormser, The Power of a Corporation To Acquire Its Own Stock, 24 YALE L.J. 177, 183 (1915); 14 S.C.L.Q. 555 (1962). See, e.g., Clapp v. Peterson, 104 11l. 26 (1882); Dupee v. Boston Water Power Co., 114 Mass. 37 (1873); Gilchrist v. Highfield, 140 Wis. 476, 123 N.W. 102 (1909).

${ }_{12}$ See I ABA-ALI MODEl Bus. CORP. ACT ANN. § 5, q 2.02-.03 (1960, Supp. 1964).

${ }^{18}$ See, e.g., Del. Code ANn. tit. 8, $\$ 160$ (1953) (impairment of capital); Fla. Stat, ANN. $\$ 608.13$ (9) (b) (I956) (surplus); IND. ANN. STAT. \$ 25-202 (8) (1960) (impairment of capital); Kan. Gen. Stat. ANN. § 17-3004 (Supp. 196l) (surplus); N.H. Rev. Stat. ANN. $\$ 294: 28$ (1955) (earned surplins).

" See, e.g., Ill. ANN Stat. ch 32, § 157.6 (Smith-Hurd Supp. 1964); N.C. GeN. STA r. $\$ 55-52$ (e) (1960).

"S South Dakota requires shareholder approval in all instances of repurchase without exception S.D C.ODF \$ 11.0303 (1939). Luuisiana and Ohio on the other 
protecting the corporation from threatened liquidation by undesirable parties seeking control. Where an extreme threat of this nature exists, power to repurchase would appear consistent with the directors' obligation to conduct the business of the corporation in a manner designed to promote the best interests of the corporation and its stockholders. ${ }^{10}$

On the other hand, in those states where stockholder approval is not required to repurchase, ${ }^{17}$ stockholders are not insulated from the possibilities of prejudice at the hands of management. Although the impossibility of concerted action by a diffuse, often disinterested, body of stockholders may not provide effective protection against the "corporate raider," the nature of the threat imposed by outsiders may be overstated by incumbent directors. ${ }^{18}$ By purchasing the shares of an insurgent, the board of directors prevents his challenge from coming to a vote, and stockholders are effectively denied the opportunity to exercise their judgment as to which management would best serve their interests. ${ }^{19}$ This tends to minimize managerial responsibility and sanctions the use of corporate funds to frustrate legitimate challenges to management policies. ${ }^{20}$

The only limitation imposed upon repurchase by the Delaware statute is that capital may not be impaired. ${ }^{21}$ Although the statute is permissive, Delaware courts have asserted their power to impose

hand require shareholder approval in all instances of repurchase except in connection with enumerated transactions, e.g., collection or compromise of a debt, claim or controversy. LA. Rev. Stat. § 12:23 (1950); OhIo Rev. CODE ANN. § 1701.35 (Page 1964).

${ }^{16}$ Accord, Bennett v. Propp, 187 A.2d 405, 408.09 (Del. Sup. Ct. 1962); Andersen v. Albert \& J. M. Anderson Mfg. Co., 325 Mass. 843, 346, 90 N.E.2d 541, 548 (1950); see Kors v. Carey, 39 Del. Ch. 47, 54.55, 158 A.2d 136, 140.41 (Ch. 1960); Kessler, Share Repurchases Under Modern Laws, 28 FordhaM L. REv. 637 n.129 (1960). See generally BaLlantine § 43 at 122.

${ }_{17}$ This includes every state except Ohio, Louisiana and South Dakota. See notes 13-15 supra and accompanying text.

${ }^{18}$ See Bennett v. Propp, 187 A.2d 405, 409 (Del. Sup. Ct. 1962), 62 Corum. L. Rev. 1096, 1100 (1962).

${ }^{10} 62$ Colum. L. Rev. 1096, 1101 (1962); 70 Yale L.J. 308, 313 (1960).

${ }^{20}$ See Manning, Book Review, 67 YalE L.J. 1477, 1486 (1958). "The courts impose on corporate agents a fiduciary obligation to 'the corporation' not to use its assets other than for its benefit (and, indirectly, the benefit of all its shareholders)...." LATTy \& Frampton, BAsic Business Associntions 317 (1963). See Andersen v. Albert \& J. M. Anderson Mfg. Co., 325 Mass. 343, 90 N.E.2d 541 (1950); BAllantine $§ 79$.

The ostensibly analogous situation in which corporate funds are used for the expenses of a proxy fight is distinguishable. The result of the expenditure is not to eliminate the need for 2 vote as is the case in stock repurchases, but, on the contrary, to allow the stockholders to vote intelligently. See 70 XaLE L.J. 308, 315 (1960).

22 See DeL. Code ANN. tit. 8, § 160 (1953). 
equitable limitations upon repurchase authorized by incumbent management. ${ }^{22}$ Manipulation of corporate funds to repurchase for personal reasons will be regarded as a breach of the directors' fiduciary obligation to the corporation. ${ }^{23}$ On the other hand, a good faith belief in the existence of a substantial threat to corporate existence will justify the purchase. ${ }^{24}$ The Cheff court extended this latter rationale by sanctioning a good faith belief in the necessity of repurchase to protect allegedly "vital" corporate policies. ${ }^{25}$

This extension of the good faith defense overlooks countervailing equities. Effective opposition to management is normally generated through the impetus of one stockholder with a large nucleus of votes. ${ }^{28}$ The language of Cheff, however, would permit the incum-

${ }^{22}$ See Bennett v. Propp, 187 A.2d 405 (Del. Sup. Ct. 1962); Kors v. Carey, 39 Del. Ch. 47, 158 A.2d 136 (Ch. 1960).

${ }^{23}$ Accord, Bennett v. Propp, 187 A.2d 405, 409 (Del. Sup. Ct. 1962); Kors v. Carey, 39 Del. Ch. 47, 54, 56, 158 A.2d 136, 140, 142 (1960); Andersen v. Albert \& J. M. Anderson Mfg. Co., 325 Mass. $343,346,90$ N.E.2d 541, 543 (1950); Gilchrist v. Highfield, 140 Wis. 476, 123 N.W. 102 (1909) (dictum).

The power to issue shares has also been used to maintain control. The same equitable limitations are imposed upon this practice as are imposed upon repurchase. Borg v. International Silver Co., 11 F.2d 147, 152 (2d Cir. 1925); Yasik v. Wachtel, 25 Del. Ch. 247, 256, 17 A.2d 309, 313 (Ch. 1941); Elliot v. Baker, 194 Mass. 518, 523, 80 N.E. 430, 452 (1907); Luther v. C. J. Luther Co., 118 Wis. 112, 123, 94 N.W. 69, 72 (1903). In one case equitable limitations were imposed upon an issue of "slares pursuant to the liquidation of a subsidiary which had held shares of the parent corporation. Macht v. Merchants Mortgage \& Credit Co., 22 Del. Ch. 74, 194 Atl. 19 (Ch. 1937).

Similar restrictions have been imposed upon proxy expenditures authorized by incumbent management. The use of proxy funds to inform stockholders of the policy issues of an election have been sustained, but the use of such funds solely to perpetuate the directors in office violates the directors' fiduciary position. One court has recognized the difficulty in applying this test. Hall v. Trans-Lux Daylight Picture Screen Corp., 20 Del. Ch. 78, 171 Atl. 226 (Ch. 1934).

24 Accord, Bennett v. Propp, 187 A.2d 405 (Del. Sup. Ct. 1962); Kors v. Carey, 39 Del. Ch. 47, 158 A.2d 136 (Ch. 1960); Martin v. American Potash \& Chem. Corp., 33 Del. Ch. 234, 92 A.2d 295 (Sup. Ct. 1952). But see Elliot v. Baker, 194 Mass. 518, 80 N.E. 450 (1907).

${ }_{25}$ "The fear of the defendants, according to their testimony, was not limited to the possibility of liquidation; it included the alternate possibility of a material change in Holland's sales policies, which the board considered vital to its future success....

....

[The board] believed, with justification, that there was a reasonable threat to the continued existence of Holland, or at least existence in its present form...." $199 \mathrm{~A} .2 \mathrm{~d}$ at 556. (Emphasis added.) Support for this extension of the good faith test may be found in Kors v. Carey, supra note 24.

The sales policy allegedly threatened in Cheff was that of directly employing retail salesmen for its products, a unique practice in the furnace industry. Maremont had indicated that this practice was not justified in terms of expense whereas management thought the practice essential. 199 A.2d at 551 .

${ }^{20}$ See Livingston, The American Stockholder 37, 62 (1958), 67 Yale L.J. 1477, 1483; 70 YaLE L.J. 308. 313 (1961). 
bent board to prevent review of their "vital" policies by buying out threatening opposition. The right of stockholders to review incumbent policy and replace management at stockholders meetings ${ }^{27}$ is an inadequate remedy when those who formulate policy may perpetuate their position with corporate funds and credit so long as they maintain a good faith belief in its importance. ${ }^{28}$

Furthermore, it would appear impossible for a court to distinguish between vital and less significant policies when measured by a subjective standard of good faith belief. For example, the reluctance of incumbent management to pay dividends may be justified by a good faith belief that improvement of market position necessitates the retention of earnings to expand existing assets. The question of good faith belief would be complicated by the possibility that incumbent management could be invoking the defense ( 1 ) to justify their primary purpose of retaining control, and (2) to prevent the recognition of ordinary income in the form of dividends on a large bloc of shares. ${ }^{29}$ Moreover, the majority of stockholders might prefer that surplus earnings be applied to dividends. It is not difficult to conceive of other examples where alleged "vital" policies may be inconsistent with stockholders' interests. ${ }^{30}$

27 See Ballantine $§ 158 ; 2$ Fletcher $\$ \S 283$, 285; Caplin, Proxies, Annual Meetings and Corporale Democracy: The Lawyer's Role, 37 VA. L. REv. 653, 656.57 (1951); 70 YAxE L.J. 308, 313 (1960). Hinckley v. Swaner, 13 Utah 2d 93, 94, 368 P.2d 709, 710 (1962); Czech Catholic Union v. Satla Realty Corp., 160 Ohio St. 545, 557, 117 N.E.2d 610, 616 (1954).

Under the Delaware statute, directors must be elected at meetings, the time and place of which are prescribed in the corporation's by-laws. DEL. CODE ANN. tit. 8, $\S 222$ (1953, Supp. 1962). The failure to conduct a valid election entitles stockholders to invoke the courts' aid in calling the meeting. DEL. CodE ANN. tit. 8, $\$ \$ 224-25$ (1953),

${ }^{28}$ Whether the threat to corporate existence or policy was in fact substantial in Cheff is questionable. Maremont controlled approximately $171 / 2 \%$ of the outstanding shares whereas the incumbent board owned approximately $23 \%$. See note 6 supra. Thus Maremont did not possess the voting power to dominate a stockholders meeting or elect his nominees to a controlling position on the board. Certainly, enough time was available for the incumbent board to secure stockholder approval of the repurchase before Maremont acquired enough shares to accomplish his alleged purpose.

${ }^{20}$ Under the Internal Revenue Code of 1954 , dividends are taxed as ordinary income to the extent they do not exceed current and accumulated earnings and profits. INT. REv. CODE of 1954, $\S 301$ (c) (1), 316 (a). This might not matter to the majority of small stockholders who are entitled to exclude up to $\$ 100$ of dividends received. INT. REv. Code of 1954, § II6 (a). But if, as in Cheff, management owned a large bloc of shares, it might be preferable for them to deter recognition of income until capital gains treatment could be aequired by a complete or substantially disproportionate redemption of shares, INT. REV. CODE OF 1954, $\S 302$ (b) (2)-(b) (3), or liquidation of the corporation. INT. REv. CODE OF 1954, $\S \S 331,346$.

${ }^{\mathrm{so}} \mathrm{At}$ this point it is unnecessary and impossible to enumerate all the sources of conflict which are resolved by a determination of incumbent polic!. The include 
It is perhaps for these reasons that the Delaware courts have altered the common law rule ${ }^{31}$ by assigning the burden of proving good faith to the defendant directors. ${ }^{32}$ The possibility of accounting to the corporation for the misuse of management power tends to discourage repurchase where a demonstrable threat to the corporation does not exist, and might encourage the submission of a proposed purchase to the stockholders.

Allowing directors to repurchase so long as they establish a good faith belief in a substantial threat of liquidation appears to be a salutary position. However, the extension of this good faith defense to protect vital business policies creates a strong possibility that existing management may invoke this defense as a masquerade to perpetuate existing control. At a minimum, the Cheff court should have required stockholder ratification of the repurchase to insure that the good faith belief of directors would be consistent with responsible corporate government.

every decision relating to the expenditure or non-expenditure of funds, such as whether to buy or lease, to sell or lease, to improve or sell, etc.

a1 Directors are generally presumed to have acted in good faith. See Bankers Sec. Corp. v. Kresge Dep't Stores, Inc., 54 F. Supp. 378 (D. Del. 1944); Rome v. Archer, 197 A.2d 49, 54 (Del. Sup. Ct. 1964); Isaacs v. Forer, 39 Del. Ch. 105, 108-09, 159 A.2d 295, 297 (Ch. 1960); Kors v. Carey, 39 Del. Ch. 47, 56, 158 A.2d 136, 142 (Ch. 1960); Davis v. Louisville Gas \& Elec. Co., 16 Del. Ch. 157, 169, 142 Atl. 654, 659 (Ch. 1928).

The difficulty of meeting this burden was illustrated in McPhail v. L. S. Starrett Co., 257 F.2d 388 (1st Cir. 1958), where the court held that even assuming the directors had an improper purpose in mind, they could not say that the plan was intended primarily to achieve this result. Id. at $395-96$.

${ }^{32}$ The Cheff court relied on its earlier decision in a similar case. $199 \mathrm{~A} .2 \mathrm{~d}$ at 554. There the court had stated: "We must bear in mind the inherent danger in the purchase of shares with corporate funds to remove a threat to corporate policy when a threat to control is involved.... Hence, in our opinion, the burden should be on the directors to justify such a purchase as one primarily in the corporate interest." Bennett v. Propp, 187 A.2d 405, 409 (Del. Sup. Ct. 1962).

When a board of directors enters into corporate transactions which will profit them personally, the burden of proving good faith is on the directors. Although these cases can be distinguished from repurchase cases in that there is no direct financial profit to the directors involved in the latter, it does not seem harsh to extend their doctrine to the situation before the court in Cheff. Unquestionably the directors will benefit personally from the resulting retention of control. See Pepper v. Litton, 308 U.S. 295, 306 (1939); Zweifach v. Scranton Lace Co., 156 F. Supp. 384, 394 (M.D. Pa. 1957); Gottlieb v. Heyden Chem. Corp., 33 Del. Ch. 82, 88, 90 A.2d 660, 663 (Sup. Ct. 1952). The court in the instant case did not hold all the directors to the same standard of proof. The two directors having a "clear pecuniary interest," both receiving salaries from the corporation, were held to a different standard of proof than the others. 199 A.2d at 554-55. However, the court does not specify what standard will be required and made no further distinction between the directors. 